\title{
Discussion on the Training Mode of Modern Marketing Talents

\author{
Zhang Fengying ${ }^{1}$ and Lin $\mathrm{Yu}^{2}$ \\ ${ }^{1}$ Institute of Technology,East China Jiaotong University \\ ${ }^{2}$ Gongqing College of Nanchang University
}

Keywords: Marketing; Talent training; Model; Compound marketing elite

\begin{abstract}
Marketing is an important economic means for enterprises to improve their economic efficiency and gain market competitiveness. In recent years, it has attracted more and more attention from enterprises. Nowadays, how to cultivate marketing talents to meet the requirements of enterprise development has become a common consensus among enterprises. On the basis of interpreting the history of marketing personnel training mode, this paper will briefly discuss the current situation of marketing personnel training mode and try to explore its way out, aiming at providing a positive role for the training of marketing talents and for the better and faster development of the enterprises.

In terms of the saturation of the talent pool in the current market, the market saturation rate of the professional marketing talents is relatively high. As it involves in various industries and fields, talent can be outputted continuously. However, for lack of actual situation, job seekers are not able to find the enterprises they want, and the enterprises are not satisfactory with the applicants. The phenomenon shows that the current elite output mode can't keep up with the demand of the enterprise for the professional compound elite. The most important thing is the lack of practical ability, which are not able to meet the requirements and abilities of the enterprises for the position. Therefore, we need to think about the output mode of the professional compound elite.
\end{abstract}

\section{The History of Modern Marketing Talents Training Mode}

With the opening of China's door to the world's foreign trade, China is emerging on the world economic stage. The huge foreign trade market enables China to continuously expand its trading market, which has been accompanied by a rising number of transactions. Behind the rapid development, there are obvious limitations on the reserve of the professional compound marketing elite. To expand the market share, we need professional marketing talents to set up the layout work. After all, he who gains talent wins the world as well as the market. Therefore, we need to accelerate reserve work of the professional compound marketing elite. At the same time, the MBA which specializes in the lack of professional compound marketing elites has begun to flourish. Some relevant associations began to be established, letting the public know the professional compound marketing elite once again through theoretical forms. In addition, some of the relevant associations have conducted seminars on various kinds of learning and communication, providing prospective theoretical guidance on how to establish the reserve and output mode of the professional compound marketing elite.

\section{The Current Situation of the Training Mode of Modern Marketing Talents}

The existing problems in the cultivation of modern marketing talents.

With the fierce competition in the world trade market and the strong demand for the development of the people's livelihood in China, how to set up the reserve and output mode of the professional compound marketing elite is the urgent matter to be solved. However, the ideal is plump, and the reality is bony. At present, we have obvious defects in education form of the professional compound marketing elite. From the perspective of education, the relevant teachers are still unable to keep up with the actual development of the society. There is a serious gap between the knowledge in textbooks and the specific needs of social practice. At the same time, the lagging form of education has also affected the students' self-development and the effective learning as well as 
deep understanding of professional knowledge. The main reason for the above-mentioned situation is that the education form of professional compound marketing elite has not been able to keep up with the times due to the late start of China's docking with the international market. On the other hand, people who enter the society from campus don't improve their professional skills according to their own business abilities, which leads to insufficient business ability.

The influence factor of modern marketing talent cultivation.

At present, what is the main problem of the serious shortage of professional compound marketing elites? From the perspective of education, the dominant direction of education still can't keep up with the actual development of the society. Although the division of labor is more detailed and the field is more professional, education still remains on the level of inclusive overview, which limits students' learning vision. The reason cans be analyzed from the following points. First, the direction of the market economy has changed. With China's entry into the global economic tide, the market marketing talent reserve has not been able to catch up with the needs and requirements of enterprises. The corresponding education form has not yet been transformed, which cannot adapt to the current division of labor. However, the cultivation of the compound marketing elites is not as practical as the theory requires. Second, there are serious constraints on the improvement of actual working ability and business level. At present, the opening of market economy makes the demand for marketers more and more vigorous. We need to make detailed planning of education form which adapts to the times and make feasible plans for the college talent output. Besides, the compound marketing elite reserve model also need to be reorganized.

\section{Discussion on the Training Mode of Modern Marketing Talents}

\section{Horizontal}

Professional compound marketing elite reserve is the mode exploration which is made for the more detailed and more professional industry requirements. Therefore, the professional compound marketing elites are cultivated from a more delicate and detailed level of social division of labor. The professional work ability and business level should be studied and promoted. In this way, an individual enterprise is provided with an individual professional compound marketing elite output, ensuring the application of the guiding talent reserve according to its actual development direction, making strong reserves for the company's next development and planning. At the same time, it is necessary to continuously improve the business ability and working level of the employees of the enterprise in accordance with the actual development situation of the market. Talents will become the mainstay of the enterprise and ensure the normal operation of the enterprise.

\section{Vertical}

Vertical professional compound marketing elite reserve is more inclined to grasp the overall market judgement and talent reserve work. Due to the continuous development of the whole enterprise, we are faced with different economic markets, so we need to subdivide the commercial value of different economic markets. There is a more professional operation in the field to do the market layout work. Therefore, it is imperative to carry out a more systematic marketing elite mode in terms of the commercial market share of different levels of economic market. In addition, due to the different subject of the market, we need to push the compound marketing elite to different market entities and take on the management needs of enterprises at all levels. In this way, they can improve their professional level and business ability, and carry out the actual work plan better from the level of the management needs. With the rapid development of the world economy, the economic market is constantly improving the demands of enterprises themselves, which leads to a deeper level of competence and business level requirements for the compound marketing elite. Therefore, we need to further study the education form and cultivation form. Throughout Marketing elite reserves the overall situation, it is necessary to conduct a horizontal and professional marketing elite reserve and vertical professional compound marketing elite reserve. The compound marketing elite reserve can be enriched to make the enterprise survive and develop, and to meet the development requirements of the current world economic market for enterprises in various fields.

At the same time, we should focus on the implementation of horizontal and vertical composite 
marketing elite reserves, which will play a very important role in promoting the social economy.

\section{References}

[1]Wu jianan ,Guo guoqin, Zhong yugan.marketing (the second version)[M].Beijing: Advanced education publishing house., 2000.

[2]Wang fanghua,Zhang xiangjing. Green marketing [M].Taiyuan: Shanxi economic publishing house., 1998.

[3] Gu guangsheng. Economic globalization and China's marketing professional talent cultivation model innovation. [J]. Market modernization,2005,(12).

[4]Wang zhanping. Marketing training [M].Wuhan: Wuhan university publishing house,2003.

[5] Sun weiren, $\mathrm{Xu}$ minyu the "virtual order" talent training mode of marketing major., he commercial economy 2014(4).

[6]Cheng jie. Design and implementation of training mode for high-end skilled marketing talents. Journal of wuhan institute of shipbuilding technology. , 2013(6).

[7]Hou jie. The reform and innovation of the training mode of high quality and skilled marketing professionals.[J]. middle school course guidance: Teaching research, 2013(20).

[8]Qin Zhongchi, Dai enyong. Thinking on the cultivation of application-oriented talents in marketing.

UJ. Consumption guidance, 2013(7). 